\title{
Developing a Sustainable Community via Community Enterprise: Approaches and Case Studies in Thailand
}

\author{
Sumalee Santipolvut ${ }^{1}$ \\ ${ }^{1}$ Faculty of Economics, Department of Economics, Kasetsart University, Bangkok, Thailand \\ Correspondence: Sumalee Santipolvut, Faculty of Economics, Department of Economics, Kasetsart University \\ 50 Ngamwongwan Rd., Lardyao, Chatuchak, Bangkok 10900, Thailand. Tel: 66-8-1354-5060. E-mail: \\ fecosus@ku.ac.th
}

\author{
Received: September 1, 2014 Accepted: December 7, 2014 Online Published: January 14, 2015 \\ doi:10.5539/ass.v11n4p150 URL: http://dx.doi.org/10.5539/ass.v11n4p150
}

\begin{abstract}
This action research project started from an analysis of the competitiveness potential of community enterprises based on Porter's Diamond Model. The SWOT analysis and TOWS Matrix are employed to determine the development plans including strategies, programmes, and details of various projects for all targeted enterprises in the five Southern border provinces of Thailand. The performances of the selected pilot projects are in line with the key performance indicators. Furthermore, all the targeted community enterprises initiating their medium-term development plans during the fiscal year 2013 to 2017 have received more revenue since project implementation. All enterprises have also expanded distribution channels, have more involvement with their communities, and the participant members of all enterprises are satisfied with the project implementation and performance at a high level. Keywords: sustainable community, community enterprise, porter's diamond model
\end{abstract}

\section{Introduction}

In Thailand, community business takes various forms. A typical example is the cottage industry under "One Tambon One Product". Such a community enterprise is legally constituted and approved by the government. In 2013, the Office of the Secretary of the Board of Community Enterprise reported that there are a total of 81,619 registered community enterprises. The businesses in the community have been continuously developed up to the Eleventh National Economic and Social Development Plan (2012-2016). Under this Plan, there is a strategy for strengthening the agricultural sector, food security, and energy to focus on building a stable occupation and steady income for farmers. Moreover, this plan aims at developing farmers and community institutions as mechanisms to enhance farmer self-reliance and to strengthen those affected by the overwhelming import of agricultural products and foods as a result of the free trade agreement. To accomplish these targets, the development of community enterprise is a necessity at national level. For this to be successful there must be clear guidelines or development plans for community enterprise suggested by community members who are involved, both directly and indirectly. This includes local, provincial, and central agencies, educational institutions, and the private sector. Despite their participation, community enterprise development in Thailand is still far behind in the development stage. The enterprises face various problems in production, such as a lack of high quality of labour and raw materials, inefficient management, and inappropriate technology. This leads to a non-standardised product, which is a drawback for competition not only on the domestic front but also in the global market.

At the global level, the concept of sustainable development has become familiar following the United Nations Conference on Environment and Development in June 1992. It has brought about the Global Action Plan for Sustainable Development, commonly known as Agenda 21. The term sustainable development has become more prevalent, and it is generally accepted that sustainable development must first take place in the community. To achieve sustainability on a wide scale, Mehta (1996) also mentions that there is a consensus that sustainability must be achieved at a local level if it is to be achieved on a global scale.

Most private businesses need to focus on participation in order to support sustainable development. The World Business Council for Sustainable Development (WBCSD) was founded in 1992 amid concerns about the impact of business operations on sustainable development and in 1997 set up a working group on the social responsibility of business. During 2000, the WBCSD included 120 companies in 20 major industrial sectors in 
30 countries with common interests in the environment, economic growth, and sustainable development to provide the guidelines for business operations as follows: (1) encourage the transition to sustainable development; (2) accelerate the linkage between businesses, the government, and other agencies concerned with the environment and sustainable development; and (3) hold a conference for the exchange of ideas to discuss the processes needed for sustainable development. Moreover, WBCSD has established a framework for sustainable development in the areas of: (1) eco-efficiency in connection with the acquisition of goods and services to meet human needs and the quality of life, reduce the impact on the ecosystem, resource shortages, and resource cycle; (2) corporate social responsibility (CSR); (3) sustainability in the market; (4) climate and energy; and (5) trade and environment.

WBCSD also set guidelines for businesses moving towards sustainable development while retaining their competitiveness. Although the main purpose of a business is to make a profit for the shareholders and investors, nowadays social responsibility must be taken into account since a business forms part of society. Social responsibility in general may include human rights, employee rights, environmental protection, supplier relations, and community involvement.

Clearly, social responsibility is not the only activity undertaken by businesses; at a more developed level the larger organisations can contribute to the community and social enterprise. Lewis et al. (2006) provided a definition of social enterprise as social organisations producing goods and services which are established by excess benefits for the purpose of investing in the community rather than to earn a profit. The United Nations Global Compact and The Rockefeller Foundation (2012) defined social enterprise as a small and medium sized enterprise intended for social and environmental benefit. The implementation of social enterprise is therefore affected by significant investment.

The Agricultural Development Department, Ministry of Agriculture and Cooperatives of Thailand has supported community enterprise development projects in five Southern border provinces to achieve its aim of evaluating potential strengths and weaknesses in the operation of target enterprises. This involves production, product development, and marketing to formulate development plans on potential evaluation while providing guidance for improving entrepreneurship at a continuously high level and select pilot plans or projects for implementation as well as monitoring and evaluating their performances. These intermediate goals are expected to lead to the ultimate goals of improved well-being, maintenance of social and cultural values, conservation and promotion of environmental quality, and a sustainable community. The author was assigned to conduct the implementation and performance evaluation of this development project.

The action research project is therefore suitable for use Michael E. Porter's Diamond Model (1990) to evaluate the competitiveness potential of the enterprise including influential environmental variable factor conditions, demand conditions, related and supporting industries, firm strategy, structure, and rivalry. We apply the Diamond Model to indicate competitiveness potential of business firms in the community, whilst others often study at the macro level by ranking the competitiveness and measure their potential through various indicators, under the assumption that the countries with the higher competitiveness, the better economic and development indicators they obtain. The main information sources used are those the famous World Economic Forum, International Institute for Development, and World Bank Data Base of Competitiveness, for instance. Besides, other studies mostly aim at analysis the impact of various environmental factors that encourage or obstacle industrial development. In these cases, they often encountered the application of such abstract or qualitative concept of Porter' Model for the quantitative indicators. These are difficult to measure the level of national competitiveness and predict how the given industry will be successful in any studied country as reported by Shafaei (2009). We, first, constructed the Diamond Model-based questionnaire in line with the contexts of community enterprises and their communities for compiling the data and information of each enterprise. We also assigned scores for each indicator in order to acquire the quantitative measurements which would be calculated to reflect the enterprise's competitiveness potential (Santipolvut et al., 2011; Santipolvut \& Sripruetkiat, 2012).

In addition, the internal and external environment is also analysed through SWOT analysis and TOWS Matrix (Piercy \& Giles, 1989), leading to the formulation of community enterprise development plans. An efficiency and effectiveness approach tool via cost-benefit analysis to measure the worthiness of selected pilot project implementation appraised by net present value (NPV), benefit-cost ratio (BCR), internal rate of return (IRR), and payback period. In addition, the quality of service provided by Kotler (1999) is used to evaluate participant satisfaction in this project. The marketing mix approach by Kotler (1997) and Boone and Kurtz (1989) and the ideas about social enterprise (Spear \& Bidet, 2003; Lewis, Hunt, \& Carson, 2006) are also applied in this project operation. 
The rest of this paper is organised as follows: Section 2 outlines the operational steps of the project and introduces a brief background of the targeted community enterprises. Section 3 elaborates on how we assess the potential of enterprise competiveness and obtain the development plan formulation, pilot project implementation, and performance monitoring and evaluation. Section 4 concludes.

\section{The Operational Steps of the Project and Background of the Targeted Community Enterprises}

\subsection{The Operational Steps of the Project}

There are five steps to the project. Firstly, to assess the competitiveness potential of the five targeted community enterprises through the Diamond Model. Secondly, to analyse the internal and external environment via the SWOT framework and TOWS Matrix. Thirdly, to formulate the medium term (three to five years) development plans for all enterprises. Fourthly, to implement the selected pilot project under the plan. Finally, to monitor and evaluate such a project. There are five key performance indicators (KPIs) to the project having its own development plan: increasing revenue, expanding distribution channels, creating more community involvement in the enterprise, providing enterprise member satisfaction in the project's implementation, and performance.

\subsection{Background of the Target Community Enterprises}

The targeted community enterprises are each located in the five Southern border provinces of Thailand. The first is Ban-Phra-bhud Agricultural Housewife Community Enterprise in Songkhla province, producing shrimp paste for cooking with its own brand - Thepha. The second is Ban-Ma-ngang Agricultural Housewife Community Enterprise in Satun province, manufacturing dried shrimp. The third is Community Enterprise Network, Pattani province. Their products are fresh and dried slide fish crackers and preserved Ka-Tak fish (similar to anchovies). The fourth is Betong Poultry Community Enterprise in Yala province. This enterprise raises native chicken named after the district where it is located - Betong. The fifth is Tak-Bai saltine Gulao Fish Community Enterprises in Narathiwat province. This enterprise produces salted Gulao fish sold in the areas and in souvenir stores in the Tak-Bai district.

\section{The Potential Assessment of Community Enterprises Competiveness and Formulation of Development Plan}

\subsection{The Potential Assessment of Community Enterprise}

Community enterprise potential is assessed as follows:

1) Determine the potential of community enterprise by using the Diamond Model as shown in Figure 1. The constructed indicators are used to develop the questionnaire for collecting data from in-depth interviews with community entrepreneurs and supportive organisations at local, district, provincial, and central levels.

2) The scoring criteria set up for the various indicators include measurements of 12 for factor conditions, 6 for demand conditions, 8 for firm strategy, structure, rivalry, and 6 for related and supporting industries.

3) Calculate a simple index of each potential aspect as shown in equation (1),

$$
D_{i}=\frac{\sum_{j=1}^{m} X_{i j}}{\sum_{j=1}^{m} \operatorname{Max} X_{i j}}
$$

where $D_{i}$ is the simple index of potential aspect i. $X_{i j}$ is the indicator $j$ for potential aspect $i, i=1,2,3,4$; for factor conditions, 2 for demand conditions, 3 for firm strategy, structure, and rivalry, and 4 for related and supporting industries. Max $\mathrm{X}_{\mathrm{ij}}$ is the highest indicator score for potential aspect $\mathrm{i}$.

4) Calculate an equal weighted composite index (CECP) to indicate the potential of community enterprise competitiveness as stated in the equation (2).

$$
\text { CECP }=\frac{\sum_{i=1}^{4} D_{i}}{4}
$$

The calculated simple indices of each potential aspect are 52, 18, 32, 24, so that the CECP is 126 .

5) Classify the potential of community enterprise into five levels based on the percentage of the composite index: $0-20 \%$ as low, $20-40 \%$ as moderately low, $40-60 \%$ as moderate level, $60-80 \%$ as moderately high, and more than $80 \%$ or above as high.

The competitiveness potential of all five community enterprises is assessed and the results are as follows: Three 
enterprises are at a moderately high level, namely, Ban-Phra-bhud Agricultural Housewife, Ban-Ma-ngang Agricultural Housewife, and Betong Poultry Community Enterprise. Pattani Community Enterprise Network and Tak-Bai Saltine Gulao Fish Community Enterprise are at moderate and moderately low levels, respectively (Table 1).

It is noteworthy that enterprises with a higher potential level would have higher demand conditions. This indicates that their products have a market need. However, some factors have limitations, especially those directly related to the ability for development within the organisation such as input factors including labour, raw materials, machinery and equipment, technology, production processes, and business administration. Related and supporting industries are assessed at a moderately high level since the enterprise is highly supported by suppliers and customers at local, district, and provincial levels. Firm strategy, structure, and rivalry are assessed at a moderate level. Enterprises still experience some problems in controlling product quality and standards, regular production volume, the main seasonal availability of raw materials, lack of financial capital, and efficient machinery and equipment in the production process. These cause a limitation of market strategy application in spite of their high market demand.

\subsection{The Formulation of Development Plans and Implementation, Monitoring and Evaluation of Pilot Projects}

\subsubsection{The Formulation of Development Plans}

Through the Diamond Model, additional analyses of the internal and external environment (SWOT) including the TOWS Matrix are applied. The approval of stakeholders in each enterprise has led to the formulation of development plans for all five enterprises in the fiscal years 2013 to 2017.

The development plans are basically categorised into five strategies: production development, input and financial capital procurement, marketing promotion, and sustainable community enterprise development. Under these strategies, programmes and projects have been determined as an urgent need during the five-year development period as mentioned above.

\subsubsection{The Implementation, Monitoring, and Evaluation of the Pilot Projects}

Ban-Phra-bhud Agricultural Housewife Community Enterprise, Songkhla province, has selected two projects for implementation: the development of machinery and equipment under the product development strategy, packaging development of a new product under the production process and product-standard improvement strategies. The first project involved the replacement of the iron machinery used for grinding shrimp paste with stainless steel to avoid corrosion and steel contamination. Such a replacement is worth the investment of 41,358 Baht for NPV, $8.30 \%$ for IRR, and a payback period of eight months. The second project is the packaging development for new ready-to-eat seasoning shrimp paste, which prolongs the product life for at least two months and viable for the market test. In summary, the two projects increase revenue for the enterprise by approximately 337,500 Baht per year and generate an income for people in the community of around 144,000-330,000 Baht annually.

Ban-Ma-hngang Agricultural Housewife Community Enterprise, Satun province, has chosen to implement two projects of tools and equipment procurement for standardised production and packaging development under the production development strategy. The first project develops stainless steel panels for drying shrimp, which increases the production capacity by 653 kilograms per year. This project is feasible with 127,567 Baht for NPV, $22.45 \%$ for IRR, and a payback period of five months. The second project is to develop a zipper fraud bag for various volume packaging operations to extend the product life by at least three months and the designed brand is unique to the product and community landscape. The two projects increase the enterprise revenue by around $1,047,000$ Baht per year and increase the income for people in the community by around 120,000 Baht annually.

Community Enterprise Network, Pattani province, has chosen the production development strategy through the implementation of equipment in the production process. New stainless steel grinding machinery for mixing fish and flour to make dough for fresh and dried slide fish crackers replaces the old, helping to reduce the production time in half and the workers by one-third. Further, pallets for drying fresh dough also reduce the use of production areas. This project is feasible with 33,463 Baht for NPV, $4.49 \%$ for IRR and a payback period of four months. Benefits from the project help the enterprise to provide education funding for children in the community.

There is a limited supply of Betong chickens due to the lack of chicken breeders and funding support to farmers. Betong Poultry Community Enterprise, Yala province, has chosen the financial capital procurement and sustainable community enterprise development strategy through project funding for the purchase of hybrid Betong chickens, animal feeds, and vaccines. Another project also includes the enterprise management structure to be sustained, 
setting a unique approach to the branding of authentic products from Betong chickens. Following implementation of the project, the income of each farmer increased to 10,376 Baht and the enterprise increased to 2,502 Baht per crop of chickens raised. In addition, chicken manure is a by-product distributed to farming members of the community enterprise and used as manure for agriculture activity in the area.

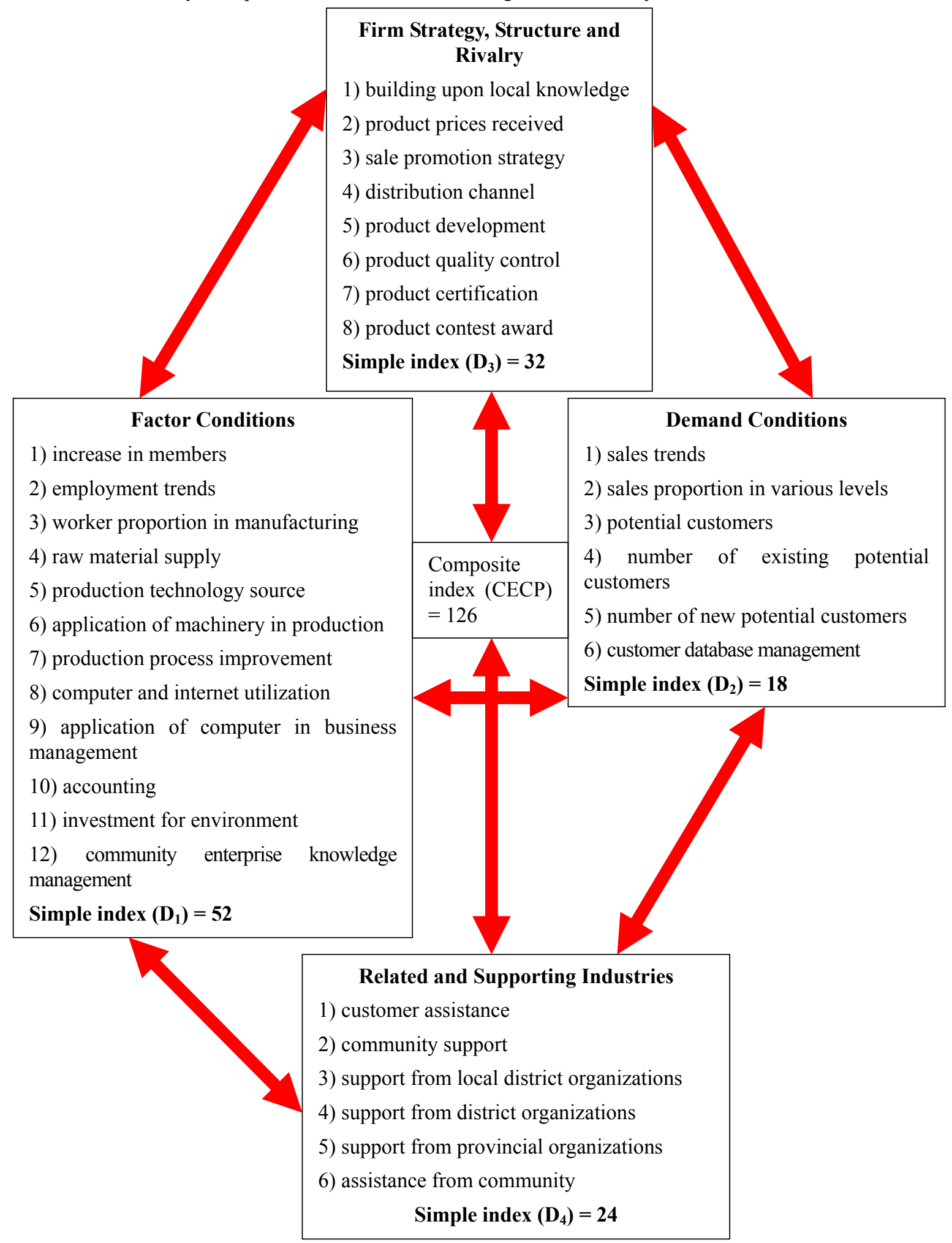

Figure 1. Indicators for assessing the potential of community enterprise competitiveness 
Table 1 . The assessment of competitiveness potential of the targeted community enterprises

\begin{tabular}{|c|c|c|c|c|c|}
\hline Community Enterprises & $\begin{array}{l}\text { Factor } \\
\text { Conditions (\%) }\end{array}$ & $\begin{array}{l}\text { Demand } \\
\text { Conditions } \\
(\%)\end{array}$ & $\begin{array}{l}\text { Related and } \\
\text { Supporting } \\
\text { Industry }(\%)\end{array}$ & $\begin{array}{l}\text { Firm Strategy, } \\
\text { Structure, and } \\
\text { Rivalry (\%) }\end{array}$ & $\begin{array}{l}\text { Potential } \\
\text { Level }\end{array}$ \\
\hline $\begin{array}{l}\text { Ban-Phra-bhud Agricultural } \\
\text { Housewife, Songkhla } \\
\text { province }\end{array}$ & 68.52 & 88.89 & 62.96 & 61.76 & $\begin{array}{l}(63.57) \\
\text { Moderately } \\
\text { high }\end{array}$ \\
\hline $\begin{array}{l}\text { Ban-Ma-ngang Agricultural } \\
\text { Housewife, Satun province }\end{array}$ & 76.36 & 83.33 & 80.77 & 60.61 & $\begin{array}{l}(73.81) \\
\text { Moderately } \\
\text { high }\end{array}$ \\
\hline $\begin{array}{l}\text { Community Enterprise } \\
\text { Network, Pattani province }\end{array}$ & 56.60 & 72.22 & 37.50 & 40.63 & $\begin{array}{l}(51.74) \\
\text { Moderate }\end{array}$ \\
\hline $\begin{array}{l}\text { Betong Poultry, Yala } \\
\text { province }\end{array}$ & 68.52 & 88.89 & 62.96 & 61.76 & $\begin{array}{l}(63.57) \\
\text { Moderately } \\
\text { high }\end{array}$ \\
\hline $\begin{array}{l}\text { Tak-Bai Saltine Gulao Fish, } \\
\text { Narathiwat province }\end{array}$ & 24.53 & 61.11 & N/A & 21.21 & $\begin{array}{l}(29.81) \\
\text { Moderately } \\
\text { low }\end{array}$ \\
\hline Average & 58.91 & 78.89 & 61.05 & 49.19 & $\begin{array}{l}(56.50) \\
\text { Moderate }\end{array}$ \\
\hline
\end{tabular}

Tak-Bai Saltine Gulao Fish Community Enterprise, Narathiwat province, has chosen the production development strategy via the project to develop fish drying equipment. The fish are covered with nets to prevent insects and be more hygienic, including the use of a heat fan for faster drying of the fish, especially on days with rain or no sun. In the production process of Gulao (salted fish), the fish heads have to be wrapped to prevent flies from laying eggs in the first four days of sun drying. The wrapping on these fish heads must be changed every day and this may take about four hours. Gulao fish production is limited. The utilisation of equipment increases Gulao production and is worth the investment with 50,989 Baht for NPV, 134\% for IRR and a payback period of eight months. In addition, entrepreneurs have developed ready-to-eat Gulao packaged in a zipper fraud bag with a unique branding linked to natural symbols of the communities.

Apart from monitoring in order to solve certain problems during project implementation and evaluating the financial and economic worthiness in the running of the pilot projects as aforementioned, the satisfaction of the participants in the project operation is also evaluated. All community enterprises evaluate their satisfaction with project performance within the range of 90-94\%, with the exception of Tak-Bai Saltine Gulao Fish Community Enterprise, Narathiwat province, which assessed its satisfaction at only $82.8 \%$ because some members did not participate in the early stages of the operation of this action research project.

\section{Summary and Conclusion}

The potential of community enterprises assessed by all 31 indicators from the applied Diamond Model indicate that the majority are at moderately high levels. The demand conditions show the highest potential, followed by related and supporting industries, factor conditions, firm strategy, structure, and rivalry respectively. Most community enterprises organise themselves quite well in selling their products. However, they suffer from limitations in production due to obsolete and inadequate machinery and equipment, and applying non-varying market strategies partially dependent upon their product packaging. Most use raw materials and their own labour force in the community as well as demonstrating sustainable linkage to their communities. Based on the Diamond Model, a SWOT analysis including TOWS Matrix is applied to formulate the development plans for all five enterprises in the fiscal year 2013 to 2017. The development plans are mainly divided into production development, input and financial capital procurement, marketing promotion, and sustainable community enterprise development strategies. Programmes and projects have been determined as extremely urgent during the period of five years of development.

For the first year of pilot project development, four out of five community enterprises selected the production development strategy through machinery and equipment to enhance their productivity and quality as well as new product packaging to prolong the product life and expand market share. Only one community has selected the financial capital procurement strategy for implementation since it lacks the necessary funds. All projects help to increase the productivity and income of the members, enterprise, and people in the community. This also includes some linkage to the community in support of sustainably-developed enterprises, use of community raw materials and labour force, 
complementing economic activities, and education in the community. This indicates that the pilot projects are financially feasible and members of all enterprises are satisfied with project performance at a high level.

This action research project offers strategic guidelines for the development of community enterprises as follows: 1) Production development includes machinery and equipment improvement to increase production capacity and product quality. 2) Marketing development includes new product development with packaging for longer shelf-life to expand the market share. 3) Financial capital procurement and business management include the internal financial logistics and structure of the community enterprises. 4) Sustainable development includes running the business sustainably and involving the community to support various aspects of its development. These guidelines for a community enterprise development plan which derived from the application of Diamond Model along with coherent implementation, monitoring, and evaluation could support sustainable development at a local level in Thailand. This would eventually bring about an achievable sustainability on a larger scale as described by Mehta (1996).

\section{References}

Charles, H., \& Boo-Chye, L. (2002). The Role of SMEs in National Economies in East Asia. Massachusetts : Edward Elgar Publishing, Inc.

Community Development Department, Ministry of Interior. (2010). A Selection of the Top Thailand's One Tambon One Product in 2010. Retrieved from http://www.thaitambon.com/OTOP2553/Summary.htm

EMES European Research Network. (1999). Definition of Social Enterprise. Retrieved from http://www.emes.net

Fraser Valley Centre for Social Enterprise. (2008). Analysis of L3C and CIC Social Enterprise Models. Canada: BC Centre for Social Enterprise.

Hashim, M. K. (2000). A Propose Strategic Framework for SMEs Success. Malaysian Management Review, 35(2), $22-43$.

Kotler, P. (1997). Marketing Management Analysis, Planning, Implementation and Control (9th ed.). Englewood Cliffs, NJ: Prentice-Hall.

Lewis, R., Hunt, P., \& Carson, D. (2006). Social Enterprise and Community-Based Care: Is There a Future for Mutually Owned Organizations in Community and Primary Care? King' Fund, Working Paper.

Mehta, P. (1996). Local agenda 21: Practical Experiences and Emerging Issues from the South. Environmental Impact Assessment Review, 16(4-6), 309-320. http://dx.doi.org/10.1016/S0195-9255(96)00029-7

National Economic and Social Development Board Office. (2011). The Eleventh National Economic and Social Development Plan. Retrieved from http://www.nesdb.go.th/Portals/0/news/plan/p11/Plan11_eng.pdf

Piercy, N., \& Giles, W. (1989). Making SWOT Analysis Work. Marketing Intelligence \& Planning, 7(5/6), 5-7. http://dx.doi.org/10.1108/EUM0000000001042

Porter, M. E. (1990). The Competitive Advantage of Nations. New York: Free Press Inc.

Riecken, H. (1952). Evaluation Action Program: Reading in Special Action Research. Boston: Allyn \& Bacon.

Rutman, L. (1977). Evaluation Research Methods: A Basic Guide. Beverly Hills, California: Sage.

Santipolvut et al. (2011). An OTOP Potential Assessment towards SMEs. Bangkok: The Centre for Applied Economics, Faculty of Economics, Kasetsart University.

Santipolvut, S., \& Sripruetkiat, K. (2012). Development of Community Enterprise in Thailand. Shanghai International Conference on Social Science (SICSS 2012), Conference Paper.

Shafaei, R. (2009). An Analytical Approach to Assessing the Competitiveness in the Textile Industry. Journal of Fashion Marketing and Management, 13(1), 20-36. http://dx.doi.org/10.1108/13612020910939851

Spear, R., \& Bidet, E. (2009). The Role of Social Enterprise in European Labour Markets. European Research Network, Working Paper.

Suchman, E. A. (1967). Evaluation Research: Principle and Practice in Public Service and Social Action Program. New York: Russels Sage Foundation.

The Northern Alliance for Sustainability. (2007). Social and Community Enterprise. Retrieved from http://www.anped.org

\section{Copyrights}

Copyright for this article is retained by the author(s), with first publication rights granted to the journal.

This is an open-access article distributed under the terms and conditions of the Creative Commons Attribution license (http://creativecommons.org/licenses/by/3.0/). 